Braz J Med Biol Res, September 2011, Volume 44(9) 914-919

doi: 10.1590/S0100-879X2011007500093

Alternative pathways for angiotensin II generation in the cardiovascular system

C. Becari, E.B. Oliveira and M.C.O. Salgado

\section{贵CNPq}

Consentonacoconald do osesenvowmento da Ciência e Tecnologia

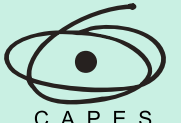

Ministério

da Educação

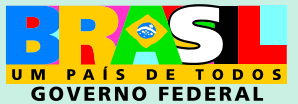

DFAPESP

Institutional S ponsors

$\sin 0_{0}$
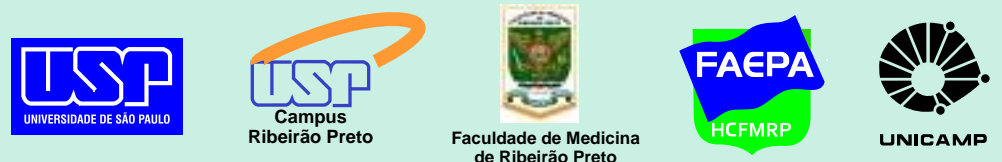

Ф SHIMADZU

Explore High - Performance MS Orbitrap Technology

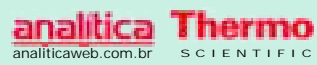




\title{
Alternative pathways for angiotensin II generation in the cardiovascular system
}

\author{
C. Becari ${ }^{1}$, E.B. Oliveira ${ }^{2}$ and M.C.O. Salgado ${ }^{1}$
}

${ }^{1}$ Departamento de Farmacologia, ${ }^{2}$ Departamento de Bioquímica e Imunologia, Faculdade de Medicina de Ribeirão Preto, Universidade de São Paulo, Ribeirão Preto, SP, Brasil

\begin{abstract}
The classical renin-angiotensin system (RAS) consists of enzymes and peptides that regulate blood pressure and electrolyte and fluid homeostasis. Angiotensin II (Ang II) is one of the most important and extensively studied components of the RAS. The beneficial effects of angiotensin-converting enzyme (ACE) inhibitors in the treatment of hypertension and heart failure, among other diseases, are well known. However, it has been reported that patients chronically treated with effective doses of these inhibitors do not show suppression of Ang II formation, suggesting the involvement of pathways alternative to ACE in the generation of Ang II. Moreover, the finding that the concentration of Ang II is preserved in the kidney, heart and lungs of mice with an ACE deletion indicates the important role of alternative pathways under basal conditions to maintain the levels of Ang II. Our group has characterized the serine protease elastase-2 as an alternative pathway for Ang II generation from Ang I in rats. A role for elastase-2 in the cardiovascular system was suggested by studies performed in heart and conductance and resistance vessels of normotensive and spontaneously hypertensive rats. This mini-review will highlight the pharmacological aspects of the RAS, emphasizing the role of elastase-2, an alternative pathway for Ang II generation.
\end{abstract}

Key words: Renin-angiotensin system; Angiotensin II; Rat elastase-2; Alternative pathway; Angiotensin-converting enzyme

\section{Renin-angiotensin system}

It is well established that the main end-product of the renin-angiotensin system (RAS), angiotensin II (Ang II), plays a key role in regulating cardiovascular homeostasis, acting both on the regulation of blood volume and peripheral vascular resistance (1). In recent years, however, several studies have shown that the RAS presents a much greater complexity than previously thought. Many peptides that were considered to be inactive metabolites had their biological activity recognized. Angiotensin III (Ang III), which is formed from Ang II by the action of aminopeptidase A, induces aldosterone release (2). Angiotensin IV (Ang IV), formed from Ang III by aminopeptidase $\mathrm{N}$, has an important role in the central nervous system, especially related to memory, and also displays proliferative effects (3). Angiotensin 1-7 (Ang-(1-7)), via activation of the MAS receptor, seems to have effects opposite to those mediated by Ang II. Another carboxypeptidase homologous to angiotensin-converting enzyme (ACE), called ACE-2, was simultaneously identified by two groups $(4,5)$. ACE-2 cleaves Ang I and Ang II to generate Ang-(1-9) and Ang-(1-7), respectively. It is important to note that so far no direct biological activity for the Ang-(1-9) fragment was described, and it is suggested that this peptide can compete with Ang I by binding the active site of ACE, which then generates Ang-(1-7) from Ang-(1-9) (Figure 1).

The effects of the angiotensin peptides are exerted via activation of different angiotensin receptors, such as type 1 (AT1), type 2 (AT2), type 4 (AT4), and MAS (1). AT1 receptors are expressed in the lungs, liver, kidney, heart, blood vessels, brain, adrenal glands, and various endocrine glands (6), and are activated by Ang II. AT1 receptors can also be stimulated by other mediators of the RAS with lower binding affinity, such as Ang III, Ang IV, and Ang-(1-7). AT2 receptors are predominantly expressed in fetal tissues (a situation reversed after birth), and are also expressed in situations of injury. Ang II and Ang-(1-7) are ligands for the AT2 receptors whose activation leads to vasodilation and anti-proliferative effects. AT2-induced effects seem to antagonize the effects induced by AT1 activation (7). Ang IV binds to the AT4 receptor that is located in the brain, heart, lungs, liver, and kidneys, being related to cognitive functions and proliferative effects $(8,9)$. The MAS receptor

Correspondence: C. Becari, Departamento de Farmacologia, Faculdade de Medicina de Ribeirão Preto, USP, Av. Bandeirantes, 3900, 14049-900 Ribeirão Preto, SP, Brasil. Fax: +55-16-3602-3040. E-mail: cbecari@usp.br

Presented at the XV Simpósio Brasileiro de Fisiologia Cardiovascular, São Paulo, SP, Brazil, February 2-5, 2011.

Received February 9, 2011. Accepted July 8, 2011. Available online July 22, 2011. Published September 16, 2011. 
is activated by Ang-(1-7), inducing vasodilation and antiproliferative effects (10).

ACE inhibitors are widely used not only in the treatment of hypertension, but also in other cardiovascular diseases (or diseases related to them) such as heart failure, myocardial infarction, renal failure, and diabetic nephropathy (11). Results of numerous clinical studies $(12,13)$ have established that blockade of the RAS with ACE inhibitors results in significant reduction of mortality in patients with heart failure or post-myocardial infarction. Since the benefits for survival were demonstrated with differentACE inhibitors, and all have common mechanisms, this important effect is attributed to ACE inhibition. Pharmacological studies show that ACE inhibitors may differ in their affinity for tissue ACE, but the clinical significance of this observation remains to be demonstrated (11).

In the last decade, evidence has accumulated showing that Ang II acts as a circulating hormone, and may also be formed locally in various tissues, acting as an autocrine or paracrine hormone and inducing a broad spectrum of effects on the cardiovascular and renal systems $(14,15)$. Although the beneficial effects of the use of ACE inhibitors in the treatment of hypertension and heart failure, among other diseases, are well known, it has been reported that patients chronically treated with effective doses of these inhibitors do not show suppression of Ang II formation $(16,17)$, suggesting the involvement of alternative pathways for Ang II generation. Moreover, the finding that the concentration of Ang II is maintained in the kidney, heart and lungs of mice with ACE deletion (18) indicates an important role of alternative pathways to maintain basal levels of Ang II.

\section{Alternative pathways for Ang II generation}

Several studies have shown the involvement of other enzymes, in addition to ACE, in the generation of Ang II (19-21). The first descriptions of an alternative pathway for Ang II formation were reported by Boucher et al. (22) in the submandibular glands of rats, by Cornish et al. (23) in the hamster cheek, and by Trachte and Lefer (24) in the cat cardiac papillary muscle. Cornish et al. (23) demonstrated that the vasoconstrictor response induced by Ang I in blood vessels of the hamster cheek pouch was only partially blocked by ACE inhibitors but completely abolished by Ang II receptor antagonists, leading to the conclusion that this vascular bed converts significant amounts of Ang I to Ang II by a route that does not involve ACE. Cornish et al. (25) also observed the formation of Ang II in- dependently of ACE in the coronary artery of hamsters. Some years later, Okunishi et al. (26) identified an Ang Il-generating enzyme in dog mesenteric artery, which was sensitive to chymostatin and insensitive to ACE inhibitors. Urata et al. (27) demonstrated in vitro two pathways for the formation of Ang II in homogenates of human heart. These investigators observed that approximately $80 \%$ of the total formation of Ang II was associated with the presence of an unknown serine protease, whereas ACE-dependent Ang II generation was only responsible for approximately $11 \%$ of total Ang II. This cardiac serine protease was purified and identified as a new member of the chymase family, and was named human heart chymase (28).

Although several enzymes can produce Ang II in vitro through cleavage of the $\mathrm{Phe}^{8}-\mathrm{His}^{9}$ bond of Ang I, their in vivo activity cannot be demonstrated. Moreover, some of these enzymes, such as trypsin, chymotrypsin and rodent chymases, also degrade Ang II (29). Data generated from the susceptibility of these different enzymes to protease inhibitors have allowed the classification of Ang Il-forming enzymes into three categories (30). The first category corresponds to metallodipeptidyl carboxypeptidase known as ACE. The second category comprises the aprotinin-sensitive serine proteases, such as kallikrein (31), trypsin (30), tonin (22), and cathepsin G (32). The third category includes a group of chymostatin-sensitive serine proteases, such as the chymostatin-sensitive Ang II-generating enzyme found in the dog mesenteric artery (33), human chymase $(27,28)$ and the rat elastase-2 enzyme $(34,35)$. These two chymostatin-sensitive serine proteases, human chymase 
and rat elastase-2, have been well characterized as ACEindependent pathways for Ang II formation in vascular tissue (36-39).

Despite the different characteristics of chymases in different species, these enzymes are functionally relevant in the ACE-independent formation of Ang II $(33,40,41)$. The determination of distinct functional activities for ACE and chymases has been possible in some cases by the use of selective inhibitors (42) and substrates (43). The development of the compound Z-lle-Glu-Pro-Phe-CO2H (CH5450), a peptide inhibitor of human heart chymase (42), provided an important pharmacological tool to investigate the enzymes responsible for tissue Ang II formation (41). Evidence that enzymatic ACE-independent pathways are functional in the conversion of precursors of circulating Ang II was provided by in vivo experiments (43-47) using the synthetic peptide [D-Pro ${ }^{11}-\mathrm{Ala}^{12}$ ]-Ang I. This biologically inactive Ang II precursor selectively releases Ang II after incubation with human chymase, but not with ACE or carboxypeptidases (43). This substrate has been used as a tool to demonstrate the role of chymases in the formation of Ang II in preparations derived from human tissues (41), primates $(43,44)$, hamsters $(46)$, dogs $(48)$, cats $(45)$, and even rats (47), a species that lacks chymase-dependent Ang II-forming activity.

The chymases are described as an alternative pathway to ACE for Ang II generation. However, depending on the species studied, chymase may be generating or degrading Ang II. Kunori et al. (49) showed that the kinetics of Ang II formation by chymases from different species followed the order dog $>$ human $>$ hamster $>$ mouse $>$ rat $(\mathrm{Kcat} / \mathrm{km}$ : $18,11,0.69,0.059,0.0030 \mathrm{mM} / \mathrm{min}$, respectively), whereas the Ang II-degrading activity of chymases is: hamster $>$ rat $>$ mouse $>$ $\operatorname{dog}($ Kcat $/ \mathrm{km}:$ 5.4, 4.8, 0.39, $0.29 \mathrm{mM} / \mathrm{min}$, respectively), indicating that human chymase has only Ang II-generating activity, whereas rat chymase exhibits Ang II-degrading activity. We have recently described a serine protease, a member of the chymotrypsin-like elastase family, named elastase $2 \mathrm{~A}$, which is secreted in the rat mesenteric arterial bed and features Ang II-forming activity $(34,38)$.

\section{Rat elastase-2}

We demonstrated the existence of some peptidases in the perfusate of the isolated rat mesenteric bed (50). The recirculating perfusion solution accumulated endo- and exo-soluble peptidases, among which a serine protease insensitive to captopril and capable to form Ang II from Ang I was iden- tified. Later, this Ang II-forming serine protease of the rat mesenteric arterial bed perfusate was isolated and purified by a combination of filtration and affinity chromatography (34). The enzyme was sensitive to chymostatin and was identified as a glycoprotein with a molecular mass of 28.5 $\mathrm{kDa}$. The amino-terminal sequence of the first ten residues of this enzyme was found to be identical to the rat pancreatic elastase-2 (EC 3.4.21.71) and the enzyme was called Ang II-forming elastase-2 of rat mesenteric arterial bed perfusate. The sequencing of cDNAs for pancreatic elastase-2 and rat mesenteric arterial bed showed that they were identical (51). The sequences were also identical to that previously published by MacDonald et al. (52) for elastase- 2 from rat pancreas. At present, elastase- 2 is the only representative of this family of proteases that is secreted outside the digestive tract and is involved in Ang II generation. The mRNA for elastase-2 was also detected in other tissues, such as lungs, heart, kidney, liver, spleen, and carotid artery (38).

A notable feature of elastase-2 as an Ang l-converting enzyme is that it does not destroy the Ang II product formed by only one cleavage (Figure 2) (34). This characteristic is shared with some chymases, such as human (27), baboon (43), and dog (53) chymases, but not with the

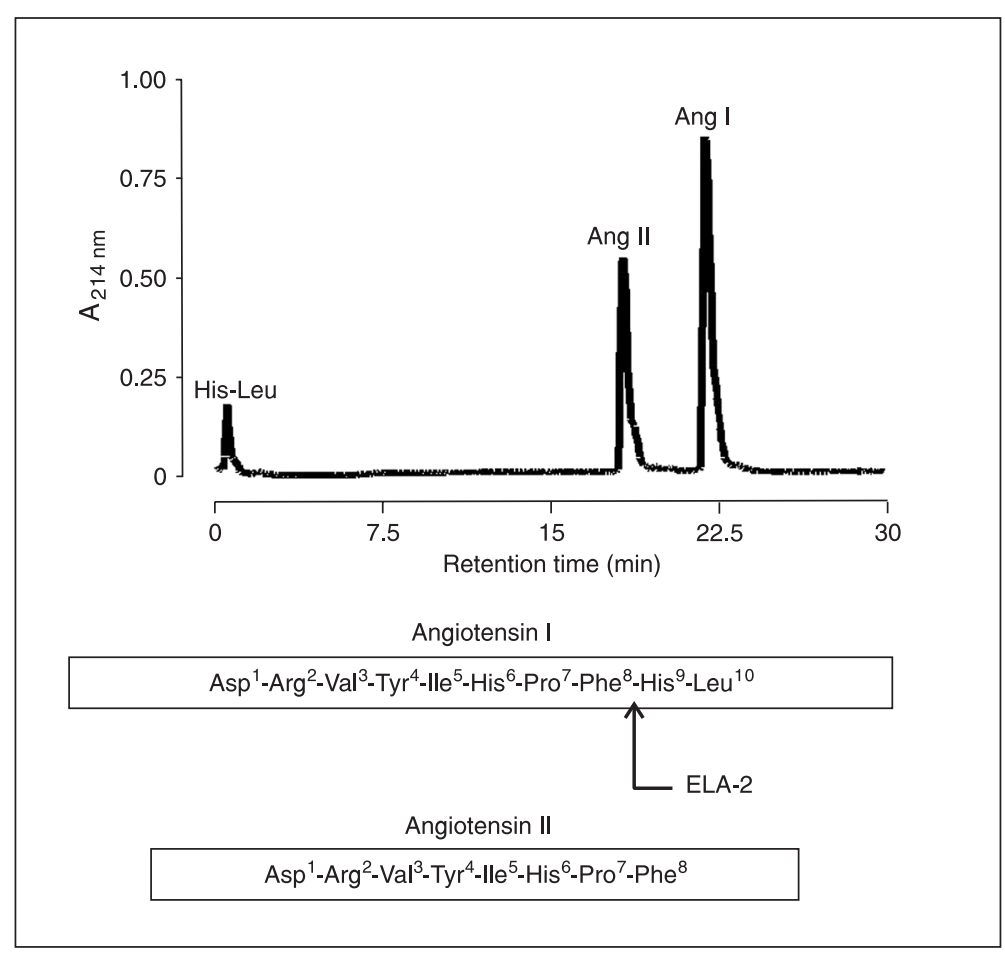

Figure 2. Hydrolysis of angiotensin I (Ang I) by the action of Ang II-forming enzyme purified from rat. Ang I $(10 \mathrm{nmol})$ was incubated with $30 \mu \mathrm{g}$ elastase-2 (ELA-2) enzyme for $30 \mathrm{~min}$ at $37^{\circ} \mathrm{C}$. The products of hydrolysis were separated by reversed-phase HPLC with an acetonitrile gradient. 
majority of rodent chymases, such as the rat and mouse, that are mainly Ang II-degrading enzymes $(29,49,54)$. Rat and mouse elastase- 2 has only Ang II-forming activity. Its catalytic activity for the conversion of Ang I to Ang II is high (Kcat $/ \mathrm{km}=42.5 \mathrm{mM} / \mathrm{min})$. The fact that elastase-2 interacts with [D-Pro ${ }^{11}-\mathrm{Ala}^{12}$ ]-Ang I and is sensitive to $\mathrm{CH} 5450$ (35), both regarded as a selective substrate and inhibitor for human chymase, suggests that the formation of Ang II by chymases in vivo, particularly in the rat, may have been overestimated in previous studies addressing Ang Il-forming alternative pathways. In addition, as described for tonin, elastase-2 can also generate Ang II directly from angiotensinogen $(22,34,55)$.

A functional role for elastase-2, as an alternative Ang II-generating pathway in the rat vasculature, was suggested by our laboratory. By using a conductance vessel (carotid) we demonstrated that ACE and elastase-2 are synergistically involved in the generation of Ang II from Ang I in physiological conditions (39). We recently demonstrated that chronic treatment of normotensive and spontaneously hypertensive rats with enalapril induces greater participation of serine proteases in the formation of Ang II from Ang I. This chymostatin-sensitive Ang II generation is markedly increased in the carotid arteries from hypertensive rats and the analysis of elastase- 2 mRNA expression showed an

\section{References}

1. de Gasparo M, Catt KJ, Inagami T, Wright JW, Unger T. International union of pharmacology. XXIII. The angiotensin II receptors. Pharmacol Rev 2000; 52: 415-472.

2. Zager PG, Luetscher JA. Effects of angiotensin III and ACTH on aldosterone secretion. Clin Exp Hypertens A 1982; 4: 1481-1504.

3. Albiston AL, Mustafa T, McDowall SG, Mendelsohn FA, Lee J, Chai SY. AT4 receptor is insulin-regulated membrane aminopeptidase: potential mechanisms of memory enhancement. Trends Endocrinol Metab 2003; 14: 72-77.

4. Tipnis SR, Hooper NM, Hyde R, Karran E, Christie G, Turner AJ. A human homolog of angiotensin-converting enzyme. Cloning and functional expression as a captopril-insensitive carboxypeptidase. J Biol Chem 2000; 275: 33238-33243.

5. Donoghue M, Hsieh F, Baronas E, Godbout K, Gosselin M, Stagliano N, et al. A novel angiotensin-converting enzymerelated carboxypeptidase (ACE2) converts angiotensin I to angiotensin 1-9. Circ Res 2000; 87: E1-E9.

6. Chiu AT, Herblin WF, McCall DE, Ardecky RJ, Carini DJ, Duncia JV, et al. Identification of angiotensin II receptor subtypes. Biochem Biophys Res Commun 1989; 165: 196203.

7. Carey RM, Wang ZQ, Siragy HM. Role of the angiotensin type 2 receptor in the regulation of blood pressure and renal function. Hypertension 2000; 35: 155-163.

8. Swanson GN, Hanesworth JM, Sardinia MF, Coleman JK, Wright JW, Hall KL, et al. Discovery of a distinct binding site for angiotensin II (3-8), a putative angiotensin IV receptor. Regul Pept 1992; 40: 409-419. increased elastase-2 message in carotid arteries of hypertensive rats. It is interesting to note that increased expression of elastase- 2 associated with chronic ACE inhibition is not restricted to the carotid artery, since similar results were observed in hearts of hypertensive rats, indicating that increased expression of elastase-2 upon ACE inhibition may be a widespread phenomenon $(56,57)$. Our recent discovery of elastase-2 as an alternative Ang II-generating pathway in the vasculature indicates that this enzyme may be important in diseases such as arterial hypertension.

The current awareness of the functional complexity of the multifaceted, multicomponent RAS has been reinforced by the identification of different proteases that can process both Ang I and Ang II to generate active metabolites, which can trigger opposing biological responses and might play peculiar regulatory roles in the local RAS. The existence of other enzymes besides ACE generating Ang II, the so-called alternative pathways of Ang II generation, such as human chymase and rat elastase-2, suggests that these proteases may have a role in physiopathological conditions and may underlie the cardiovascular effects of ACE inhibitors.

\section{Acknowledgments}

Research supported by FAPESP and CNPq.
9. Unger T, Chung O, Csikos T, Culman J, Gallinat S, Gohlke P, et al. Angiotensin receptors. J Hypertens Supp/ 1996; 14: S95-S103.

10. Santos RA, Simoes e Silva AC, Maric C, Silva DM, Machado $\mathrm{RP}$, de Buhr I, et al. Angiotensin-(1-7) is an endogenous ligand for the $G$ protein-coupled receptor Mas. Proc Natl Acad Sci U S A 2003; 100: 8258-8263.

11. Dzau VJ, Bernstein K, Celermajer D, Cohen J, Dahlof B, Deanfield J, et al. Pathophysiologic and therapeutic importance of tissue ACE: a consensus report. Cardiovasc Drugs Ther 2002; 16: 149-160.

12. Effect of enalapril on survival in patients with reduced left ventricular ejection fractions and congestive heart failure. The SOLVD Investigators. N Engl J Med 1991; 325: 293302.

13. Torp-Pedersen C, Kober L. Effect of ACE inhibitor trandolapril on life expectancy of patients with reduced left-ventricular function after acute myocardial infarction. TRACE Study Group. Trandolapril Cardiac Evaluation. Lancet 1999; 354: 9-12.

14. Dzau VJ. Circulating versus local renin-angiotensin system in cardiovascular homeostasis. Circulation 1988; 77: I4-I-13.

15. Bader M, Ganten D. Update on tissue renin-angiotensin systems. J Mol Med 2008; 86: 615-621.

16. Jorde UP, Ennezat PV, Lisker J, Suryadevara V, Infeld J, Cukon S, et al. Maximally recommended doses of angiotensin-converting enzyme (ACE) inhibitors do not completely prevent ACE-mediated formation of angiotensin II in chronic 
heart failure. Circulation 2000; 101: 844-846.

17. Farquharson CA, Butler R, Hill A, Belch JJ, Struthers AD. Allopurinol improves endothelial dysfunction in chronic heart failure. Circulation 2002; 106: 221-226.

18. Wei CC, Ferrario CM, Brosnihan KB, Farrell DM, Bradley WE, Jaffa AA, et al. Angiotensin peptides modulate bradykinin levels in the interstitium of the dog heart in vivo. $J$ Pharmacol Exp Ther 2002; 300: 324-329.

19. Campbell DJ. Circulating and tissue angiotensin systems. $J$ Clin Invest 1987; 79: 1-6.

20. Balcells E, Meng QC, Johnson WH Jr, Oparil S, Dell'Italia LJ. Angiotensin II formation from ACE and chymase in human and animal hearts: methods and species considerations. Am J Physiol 1997; 273: H1769-H1774.

21. Takai S, Sakaguchi M, Jin D, Yamada M, Kirimura K, Miyazaki M. Different angiotensin II-forming pathways in human and rat vascular tissues. Clin Chim Acta 2001; 305: 191-195.

22. Boucher R, Demassieux S, Garcia R, Genest J. Tonin, angiotensin II system. A review. Circ Res 1977; 41: 26-29.

23. Cornish KG, Joyner WL, Gilmore JP. Direct evidence for the presence of a different converting enzyme in the hamster cheek pouch. Circ Res 1979; 44: 540-544.

24. Trachte GJ, Lefer AM. Inotropic and vasoactive effects of the naturally occurring angiotensins in isolated cat cardiac muscle and coronary arteries. Res Commun Chem Pathol Pharmacol 1979; 25: 419-427.

25. Cornish KG, Joyner WL, Gilmore JP. Evidence for the conversion of angiotensin I to angiotensin II by the coronary microcirculation. Blood Vessels 1979; 16: 241-246.

26. Okunishi $\mathrm{H}$, Miyazaki M, Toda N. Evidence for a putatively new angiotensin Il-generating enzyme in the vascular wall. J Hypertens 1984; 2: 277-284.

27. Urata H, Healy B, Stewart RW, Bumpus FM, Husain A. Angiotensin II-forming pathways in normal and failing human hearts. Circ Res 1990; 66: 883-890.

28. Urata H, Kinoshita A, Misono KS, Bumpus FM, Husain A. Identification of a highly specific chymase as the major angiotensin II-forming enzyme in the human heart. J Biol Chem 1990; 265: 22348-22357.

29. Le Trong H, Neurath H, Woodbury RG. Substrate specificity of the chymotrypsin-like protease in secretory granules isolated from rat mast cells. Proc Natl Acad Sci U S A 1987; 84: 364-367.

30. Arakawa K. Serine protease angiotensin II systems. J Hypertens Suppl 1996; 14: S3-S7.

31. Maruta $\mathrm{H}$, Arakawa K. Confirmation of direct angiotensin formation by kallikrein. Biochem J 1983; 213: 193-200.

32. Tonnesen MG, Klempner MS, Austen KF, Wintroub BU. Identification of a human neutrophil angiotension II-generating protease as cathepsin G. J Clin Invest 1982; 69: 25-30.

33. Okunishi H, Miyazaki M, Okamura T, Toda N. Different distribution of two types of angiotensin II-generating enzymes in the aortic wall. Biochem Biophys Res Commun 1987; 149: 1186-1192.

34. Paula CA, Sousa MV, Salgado MC, Oliveira EB. Purification and substrate specificity of an angiotensin converting elastase-2 from the rat mesenteric arterial bed perfusate. Biochim Biophys Acta 1998; 1388: 227-238.

35. Santos CF, Paula CA, Salgado MC, Oliveira EB. Kinetic characterization and inhibition of the rat MAB elastase-2, an angiotensin I-converting serine protease. Can J Physiol Pharmacol 2002; 80: 42-47.
36. McDonald JE, Padmanabhan N, Petrie MC, Hillier C, Connell JM, McMurray JJ. Vasoconstrictor effect of the angiotensin-converting enzyme-resistant, chymase-specific substrate [Pro(11)(D)-Ala(12)] angiotensin I in human dorsal hand veins: in vivo demonstration of non-ACE production of angiotensin II in humans. Circulation 2001; 104: 18051808.

37. Richard V, Hurel-Merle S, Scalbert E, Ferry G, Lallemand F, Bessou JP, et al. Functional evidence for a role of vascular chymase in the production of angiotensin II in isolated human arteries. Circulation 2001; 104: 750-752.

38. Santos CF, Caprio MA, Oliveira EB, Salgado MC, Schippers $\mathrm{DN}$, Munzenmaier DH, et al. Functional role, cellular source, and tissue distribution of rat elastase-2, an angiotensin IIforming enzyme. Am J Physiol Heart Circ Physiol 2003; 285: $\mathrm{H} 775-\mathrm{H} 783$.

39. Becari C, Sivieri DO Jr, Santos CF, Moyses MK, Oliveira EB, Salgado MC. Role of elastase-2 as an angiotensin II-forming enzyme in rat carotid artery. J Cardiovasc Pharmacol 2005; 46: 498-504.

40. Urata H, Nishimura H, Ganten D, Arakawa K. Angiotensinconverting enzyme-independent pathways of angiotensin II formation in human tissues and cardiovascular diseases. Blood Press Suppl 1996; 2: 22-28.

41. Waldeck K, Lindberg BF, Persson K, Andersson KE. Characterization of angiotensin II formation in human isolated bladder by selective inhibitors of ACE and human chymase: a functional and biochemical study. Br J Pharmacol 1997; 121: 1081-1086.

42. Bastos M, Maeji NJ, Abeles RH. Inhibitors of human heart chymase based on a peptide library. Proc Natl Acad Sci U S A 1995; 92: 6738-6742.

43. Hoit BD, Shao Y, Kinoshita A, Gabel M, Husain A, Walsh RA. Effects of angiotensin II generated by an angiotensin converting enzyme-independent pathway on left ventricular performance in the conscious baboon. $J$ Clin Invest 1995; 95: 1519-1527.

44. Mangiapane ML, Rauch AL, MacAndrew JT, Ellery SS, Hoover KW, Knight DR, et al. Vasoconstrictor action of angiotensin I-convertase and the synthetic substrate (Pro11,DAla12)-angiotensin I. Hypertension 1994; 23: 857-860.

45. Garrison EA, Champion HC, Kadowitz PJ. [Pro11,D-Ala12] angiotensin I has rapid onset vasoconstrictor activity in the cat. Am J Physiol 1997; 273: E1059-E1064.

46. Nishimura $H$, Buikema $H$, Baltatu $O$, Ganten $D$, Urata $H$. Functional evidence for alternative ANG II-forming pathways in hamster cardiovascular system. Am J Physiol 1998; 275: $\mathrm{H} 1307-\mathrm{H} 1312$

47. Inoue K, Nishimura $\mathrm{H}$, Kubota J, Kawamura K. Alternative angiotensin II formation in rat arteries occurs only at very high concentrations of angiotensin I. Hypertension 1999; 34: 525-530.

48. Murakami M, Matsuda H, Kubota E, Wakino S, Honda M, Hayashi K, et al. Role of angiotensin II generated by angiotensin converting enzyme-independent pathways in canine kidney. Kidney Int Supp/ 1997; 63: S132-S135.

49. Kunori $Y$, Muroga $Y$, lidaka $M$, Mitsuhashi $H$, Kamimura $T$, Fukamizu A. Species differences in angiotensin II generation and degradation by mast cell chymases. J Recept Signal Transduct Res 2005; 25: 35-44.

50. Oliveira EB, Salgado MC, Turner AJ. A survey of vasoactive peptide metabolizing enzymes in the rat mesenteric arterial 
bed perfusate. Biochem Pharmacol 1991; 42: 1897-1904.

51. Santos CF, Oliveira EB, Salgado MC, Greene AS. Molecular cloning and sequencing of the CDNA for rat mesenteric arterial bed elastase-2, an angiotensin II-forming enzyme. $J$ Cardiovasc Pharmacol 2002; 39: 628-635.

52. MacDonald RJ, Stary SJ, Swift GH. Rat pancreatic ribonuclease messenger RNA. The nucleotide sequence of the entire mRNA and the derived amino acid sequence of the pre-enzyme. J Biol Chem 1982; 257: 14582-14585.

53. Caughey GH, Raymond WW, Wolters PJ. Angiotensin II generation by mast cell alpha- and beta-chymases. Biochim Biophys Acta 2000; 1480: 245-257.

54. Wintroub BU, Schechter NB, Lazarus GS, Kaempfer CE, Schwartz LB. Angiotensin I conversion by human and rat chy- motryptic proteinases. J Invest Dermatol 1984; 83: 336-339.

55. Santos CF, Greene AS, Salgado MC, Oliveira EB. Conversion of renin substrate tetradecapeptide to angiotensin II by rat MAB elastase-2. Can J Physiol Pharmacol 2004; 82: 1000-1005.

56. Becari C, Teixeira FR, Oliveira EB, Salgado MC. Angiotensinconverting enzyme inhibition augments the expression of rat elastase-2, an angiotensin Il-forming enzyme. Am J Physiol Heart Circ Physiol 2011; May 20 [Epub ahead of print; doi: 10.1152/ajpheart.00534.2010].

57. Becari C, Pereira HJV, Sivieri DO Jr, Mesquita JR, Oliveira EB, Salgado MCO. Angiotensin (1-12) metabolism in cardiac perfusate of wistar and spontaneously hypertensive rats. Washignton: Hypertension, 56: 2010. p e50-e116. 